\title{
Ichthyofauna, fish supply and fishermen activities on the mid-Tocantins River, Maranhão State, Brazil
}

\author{
Garavello, JC. ${ }^{\mathrm{a}}$, Garavello, JP. ${ }^{\mathrm{b}}$ and Oliveira, $A \mathrm{~K}^{\mathrm{c}}$ \\ ${ }^{a}$ Departamento de Ecologia e Biologia Evolutiva, Universidade Federal de São Carlos - UFSCar, \\ Rodovia Washington Luís, Km 235, CEP 13565-905, São Carlos, SP, Brazil \\ brograma de Pós-graduação em Ecologia e Recursos Naturais, Universidade Federal de São Carlos - UFSCar, \\ Rodovia Washington Luís, Km 235, CEP 13565-905, São Carlos, SP, Brazil \\ 'Departamento de Hidrobiologia, Universidade Federal de São Carlos - UFSCar, \\ Rodovia Washington Luís, Km 235, CEP 13565-905, São Carlos, SP, Brazil \\ *e-mail jugaravellof@terra.com.br
}

Received July 21, 2009 - Accepted August 28, 2009 - Distributed August 31, 2010

(With 4 figures)

\begin{abstract}
This article concerns an inventory of the ichthyofauna from the main channel of the mid-Tocantins River and studies on fisheries in this region including an evaluation of activities from Colônia de Pesca Z-35 of Estreito and Carolina in Tocantins and Maranhão States, Brazil, during 1999 and 2000. This study includes taxonomy and fishery data obtained from field collections and from interviews with the fishermen, carried out in March and July of 2001. The systematic record and fishery data were obtained from the most common species of the ichthyofauna of the mid-Tocantins River. A critical examination of fish resources from this area allows us to conclude that the large commercial species have decreased in number and are qualitatively reduced in that area of Tocantins. This fact may be a result of breaking the main channel of Tocantins, first by the hydroelectric power dam of Tucurui, twenty years ago, followed by the formation of the hydroelectric reservoirs of Lageado, Peixe Angical and Serra da Mesa, that transformed the main channel of Tocantins into a successive cascade of reservoirs. Those events may perhaps modify the profile of the fish community in that area. The obtained data also permit an examination of fisheries in the area, providing an appraisal on forthcoming problems that will be faced by fishermen of Colônia de Pesca Z-35.
\end{abstract}

Keywords: neotropical, freshwater fishes, fishery and fishermen, Tocantins, Maranhão, Brazil.

\section{Ictiofauna, recursos pesqueiros e a atividade da pesca no médio Rio Tocantins no Estado do Maranhão, Brasil}

\begin{abstract}
Resumo
Este artigo versa sobre a ictiofauna e avalia o estado da atividade pesqueira nos municípios de Estreito e Carolina no médio rio Tocantins, na divisa dos estados do Maranhão e Tocantins. O artigo reúne estudos taxonômicos e apresenta dados da ictiofauna relatando sobre a atividade de pescadores nos meses de março e julho de 2001. Estes dados são complementados por uma discussão sobre dados pesqueiros obtidos junto à Colônia de Pesca Z-35 de Estreito em 1999 e 2000. O estudo da ictiofauna e dos recursos pesqueiros levantados permitiram um exame sobre as reduções e supressões de espécies comerciais ocorridas no elenco da ictiofauna do médio rio Tocantins. O estudo ainda conclui que esta redução qualitativa na ictiofauna desta área pode ser primeiramente atribuída ao fechamento da barragem da hidrelétrica de Tucurui há cerca de vinte anos e secundariamente à formação dos reservatórios das hidrelétricas, Lageado, Peixe Angical e Serra da Mesa, que transformaram a calha do Tocantins em uma cascata de reservatórios causando modificações na ictiofauna. Os dados permitem ainda a revisão da atividade pesqueira e uma análise dos problemas futuros que os pescadores da Colônia Z-35 de Estreito poderão enfrentar.
\end{abstract}

Palavras-chave: neotropical, peixes de água doce, pescadores, Tocantins, Maranhão, Brasil. 


\section{Introduction}

The Tocantins River forms, with the River Araguaia, a large delta in the main channel of the Amazon River nearly $200 \mathrm{~km}$ from the Atlantic Ocean. The Tocantins basin is located between coordinates 2 and $18{ }^{\circ} \mathrm{S}$ and 46 and $55^{\circ} \mathrm{W}$, draining near $767.000 \mathrm{~km}^{2}$ in an extension of almost $2.500 \mathrm{~km}$. Also, the Tocantins and tributaries at the studied area do not have flooded areas, lakes or marginal ponds, similar to that found in the Araguaia and rivers of other plain areas in Brazil. The absence of those large flooded marginal areas in Tocantins selects and reduces some species perhaps causing the distinction of ichthyofauna in those hydrographic systems. This area of mid-Tocantins River has several waterfalls due to declivities in the main channel and some of its fish show association to this torrential environment and some of these species are shared with the Central Amazon River.

The Tocantins River source is located in the Central Brazilian Plateau at a place known as Águas Emendadas and also shares several genera and species with Paraná and São Francisco Rivers that have headwaters on this Brazilian Plateau. The headwaters of those three hydrographic systems are in contact at Águas Emendadas, far north of Brasilia. In this area, the watershed is low permitting free contact of those water bodies and thus between their ichthyofauna. Furthermore, as the Tocantins River flows northwards, the indication of fish exchange disappears, giving to each ichthyofauna individual attributes. In view of this and progressively, the fishes from Tocantins and their more distant tributaries from the headwater assume their own characteristics, showing a particular combination of species in part originating from Águas Emendadas and in part from central Amazonia. This fact may be observed when comparing the fish records from Araguaia River with those from Tocantins (Tejerina-Garro et al., 1998). These data reveal some genera and species from Paraná River basin, especially from the Paranaiba River, such as Leporinus taeniatus, also found in the São Francisco River, Leporinus paranensis and Leporinus microphthalmus collected in Tocantins River but absent in the Araguaia River. On the other hand, Leporinus tigrinus and Leporinus unitaeniatus - this last species recently described by Garavello and Santos (2009) from Tocantins - were collected in a branch of São Simão reservoir at Paranaíba River basin, showing a probably free interchange of anostomid ichthyofauna among these rivers.

This subject is discussed in the present paper, which also attempts to appraise the status of artisanal fishery in this area, focussing on the qualitative and quantitative reduction of the large species of fish in this river after twenty years of operations of the Tucurui hydroelectric power dam. Also, fishery aspects are included concerning the data obtained near Colônia de Pesca Z-35 that recruits fishermen from the localities of Estreito and Carolina at the mid-Tocantins. Thus, taxonomy and ecological data from fishery are herein presented, attempting to examine the reduction of the ichthyologic richness occurring in this area of the Tocantins River on the advent of more and recent hydroelectric power improvements.

\section{Study Area}

This study was carried out on data collected on two visits to this area of the mid-Tocantins and in two different periods of the year including the rainy period and dry season. The visited areas are located between the municipalities of Estreito and Palmeirante on the border of Maranhão and Tocantins States, Brazil. The places where fish were collected were: 1) Estreito Pequeno (Pedral), $6^{\circ} 38^{\prime} 58^{\prime \prime} \mathrm{S}$ and $47^{\circ} 29^{\prime} 15^{\prime \prime} \mathrm{W}$; 2) Ilha dos Campos, $6^{\circ} 43^{\prime} 59^{\prime \prime} \mathrm{S}$ and $47^{\circ} 29^{\prime} 44^{\prime \prime} \mathrm{W}$; 3) Mouth of Cana Brava River, $7^{\circ} 18^{\prime} 39^{\prime \prime} \mathrm{S}$ and $47^{\circ} 38^{\prime} 29^{\prime \prime} \mathrm{W}$; 4) Mouth of Ouro River, $7^{\circ} 15^{\prime} 43^{\prime \prime} \mathrm{S}$ and $47^{\circ} 34^{\prime} 31^{\prime \prime}$ W; 5) Mouth of Tauá River, Barra do Ouro Velha, $7^{\circ} 42^{\prime}$ 6" S and 47 43' 4" W and 6) Mouth of Manuel Alves Pequeno River, $7^{\circ} 56^{\prime} 4^{\prime \prime} \mathrm{S}$ and $47^{\circ} 57^{\prime}$ ' ' 'W (see Figure 1). Those places for collecting ichthyofauna were chosen on the basis of satellite images, scale 1: 250.000 , and marked on a map with the help of GPS equipment and a Brazilian chart. The aquatic environments were chosen based on the amount of remaining gallery vegetation on the banks of Tocantins and tributaries around the municipalities of Estreito, Carolina, Barra do Ouro and Palmeirante.

The mid-Tocantins maintains some fragments of gallery vegetation, without large trees and with banks occupied by

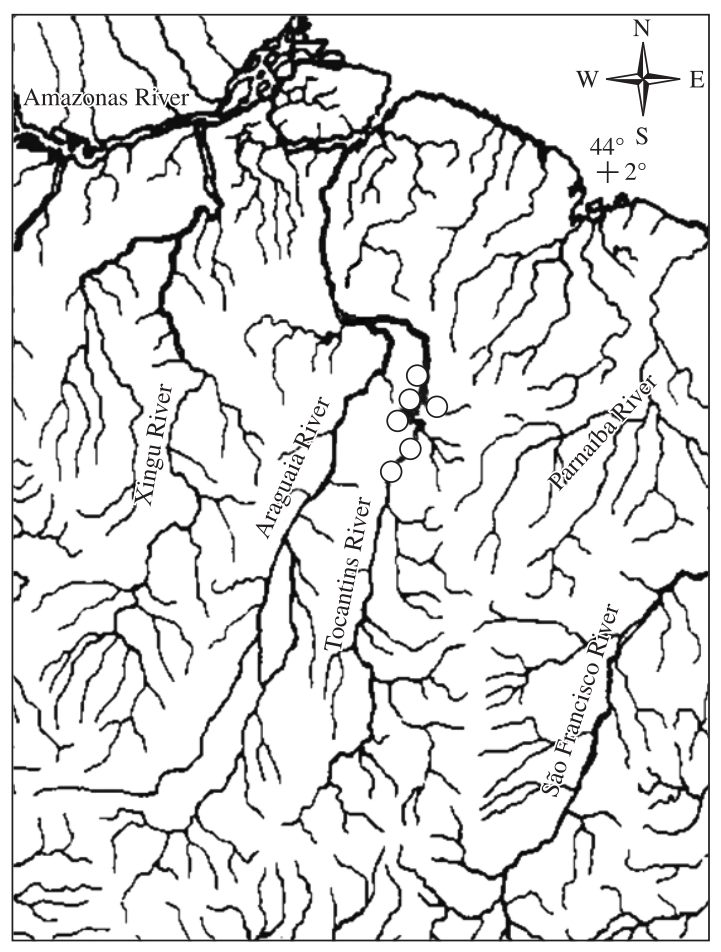

$\bigcirc$ Places where fishes were collected in Tocantins River

Figure 1. Map showing the collecting places in the mid-Tocantins River. 
human agriculture. Places with preserved gallery vegetation may be encountered only along the main tributaries. Vegetation is important to retain fish assemblage mainly when provided with falling fruits and seeds from trees into the water that attract herbivorous fishes, such as fishes of the genus Brycon that feed on fruits, fishes of genera Myleus and Mylossoma and anostomid fishes that feed on seeds and submerged roots. Piscivorous fish seems to be limited by the capacity of gallery vegetation to supply food to herbivorous fishes or primary consumers. With lack of gallery vegetation, primary consumer fish become absent and it is mostly known that lacking these fishes, secondary consumers will also disappear, giving origin to unknown reductions in the ichthyofauna as a whole.

\section{Material and Methods}

The collection of ichthyofauna was performed in two periods of 15 days in March and July, 2001, corresponding to rainy and dry seasons in the mid-Tocantins River. Fishes were collected at each place with the help of 2 to $9 \mathrm{~cm}$ mesh gill nets, which operated for 24 hours and were visited every six hours. Collection of large fishes was carried out with the help of hand nets and an "espinhel". Fishes were fixed in $10 \%$ formalin solution in the field and transferred to $70 \%$ ethanol solution in the laboratory. The collection is housed at LISDEBE-UFSCar (Laboratório de Ictiologia Sistemática do Departamento de Ecologia e Biologia Evolutiva da Universidade Federal de São Carlos). The identification of species was made with the help of the catalogue by Santos et al. (2004) and of the systematic literature. Trophic categorisation of species groups followed Hahn et al. (1998).

\section{Results and Discussion}

This study obtained 674 fish specimens, registering 50 species for the main body of Tocantins River from the area between Estreito and Palmeirante. Of the six orders represented in the collection, species of the order Characiformes represented $54 \%$ of the total and those of Siluriformes represented $28 \%$. Perciformes constituted $12 \%$ of the total, and the remaining orders, Gymnotiformes, Clupeiformes and Pleuronectiformes represented - each one - only $2 \%$ of species normally found in Tocantins in that area. Data of the two periods are ordered by place of sampling, so: 1) Estreito Pequeno; 2) Ilha dos Campos; 3) Mouth of Cana Brava River; 4) Mouth of Ouro River; 5) Mouth of Tauá River, Barra do Ouro Velha; 6) Mouth of Manoel Alves Pequeno River. Of the 50 species, 36 were registered in the first sampling (rainy period) and 30 in the second, during the dry period (Table 1).

Significant differences were found in the list of species of this study in comparison with the data collected by Merona (1987), who carried out studies before the closure of the hydroelectric power dam of Tucurui, lower Tocantins basin. Twenty years after the closure of Tucurui hydroelectric power dam, a substantial reduction in richness of fish species occurred in the mid-Tocantins River. Besides the different methods utilised by Merona (op cit.) to collect fish, in relation to the present study, it seems clear that twenty years ago the Tocantins River was richer in fish species. On the other hand, the published data by Santos et al. (2004), when added to the fishery data registered by the Colônia de Pesca Z-35 in 1999 and 2000 compiled for this study, may reflect the direct influence of the hydroelectric of Tucurui as perhaps the preponderant factor causing reduction of fish richness in that area. The main factor explaining this reduction may be associated with the absence of a mechanism of transference for the ichthyofauna from downriver to upriver that was not included in the original project of this hydroelectric dam in the past. For this reason, several generations of the fish species nearby may have disappeared from upriver and downstream of Tocantins in this area, resulting in a strong reduction in fisheries in the mid-Tocantins River in recent times.

Composition of ichthyofauna in size: Of the 50 species registered and grouped by size, we may appraise that only $20 \%$ of the species may be considered as large sized, e.g. adult individuals increase to above $40 \mathrm{~cm}$ in SL. Among these species are: Prochilodus nigricans, Hydrolycus armatus, Raphiodon vulpinus, Boulengerella cuvieri, Leporinus affinis, Schizodon vittatus, Hemisorubim platyrhynchos, Pinirampus pirinampu, Pterodoras granulosus, Oxydoras niger, Cichla ocellaris and Plagioscion surinamensis. On the other hand, nearly $30 \%$ of the species sampled may be considered as medium sized, i.e. its length in adults varies between 20 and $40 \mathrm{~cm}$ in SL. Among them: Hemiodus unimaculatus, Leporinus friderici, Hydrolycus tatauaia, Serrasalmus rhombeus, Panaque nigrolineatus, Retroculus lapidifer and Geophagus surinamensis and the pimelodids Pimelodus blochii and Pimelodella cristata. Nearly $50 \%$ of these species may be considered as small sized, i.e. their standard length is always inferior to $20 \mathrm{~cm}$, such as: Triportheus albus, T. angulatus and T. auritus, fishes of the subfamily Tetragonopterinae, curimatid fishes Steindachnerina amazonica and Curimata species and "cascudos" of family Loricariidae. Also several juvenile individuals of mixed medium and small sized species were included in this category and they appear in both periods. Collections from the dry period had obtained minute species and juveniles of other species like Panaque nigrolineatus, Steindachnerina amazonica, Salminus hilarii, Pachyurus schomburgkii, Prochilodus nigricans and Hemiodus unimaculatus.

Captures by fishery art and mesh size: The totality of 674 individuals was collected by gill nets and a lower percentage comes from trawl net collecting. The collections made with gill nets were the most representative in number of species. From the 50 species obtained, nearly $90 \%$ comes from artisinal fishing, while only $10 \%$ comes from trawl net fishing. Meanwhile, some of these species have shown wide distribution, using pelagic zones of large banks of the Tocantins River such as marginal regions of small tributaries; most of them inhabiting these areas while in the juvenile stage. Between them, Prochilodus 
Garavello, JC., Garavello, JP. and Oliveira, AK.

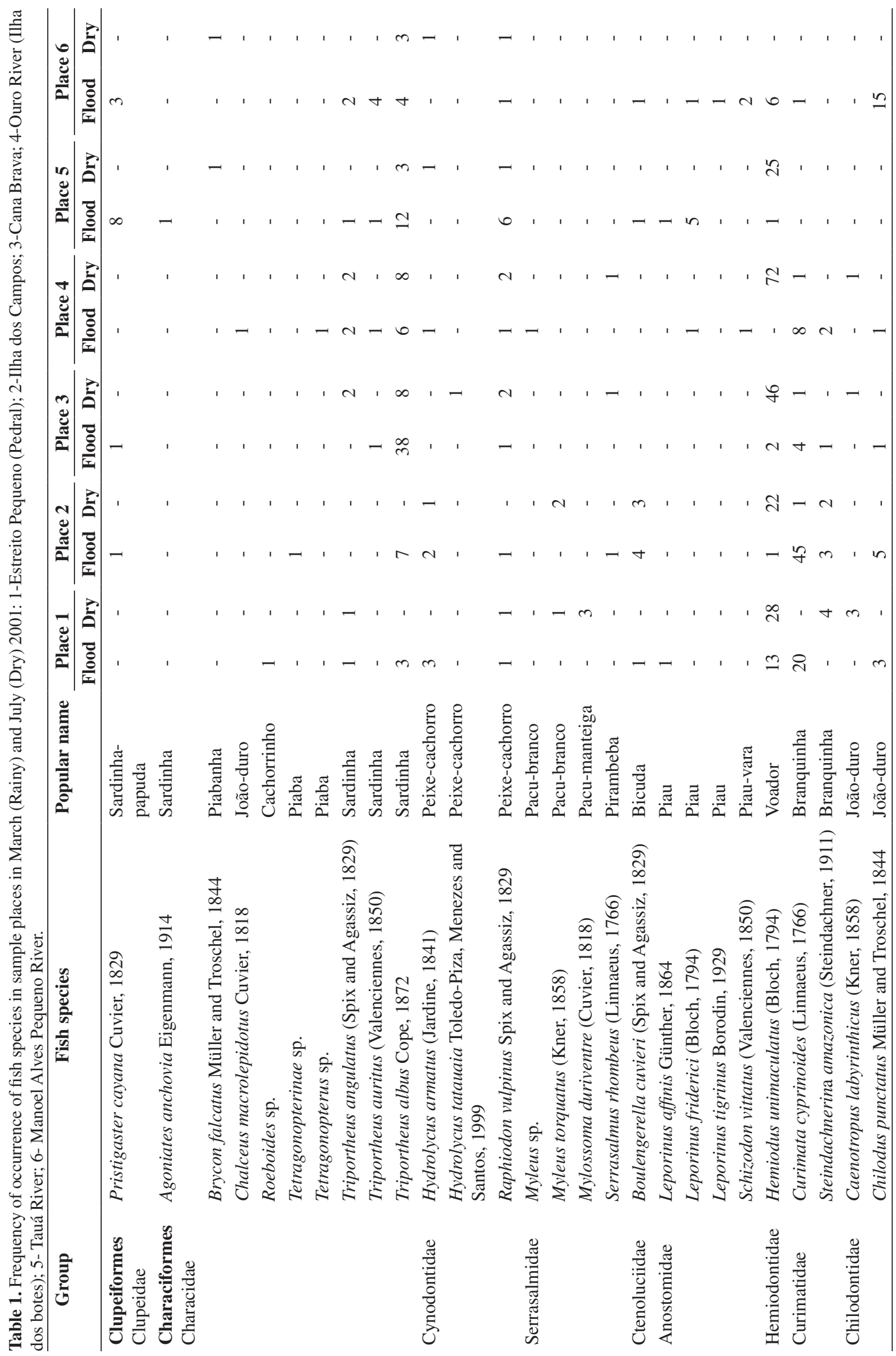




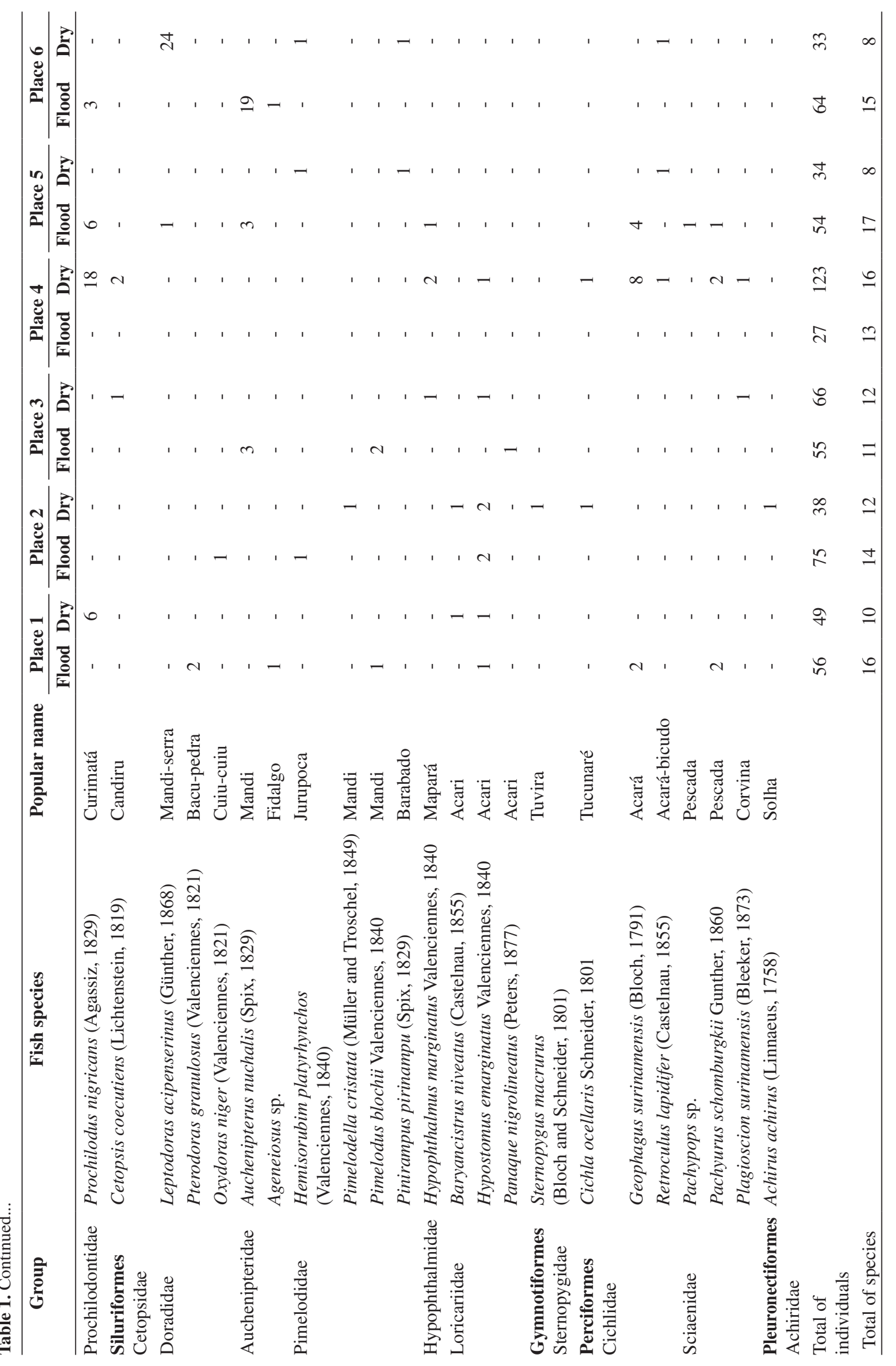


nigricans, Retroculus lapidifer, Steindachnerina amazonica, Leptodoras acipenserinus and Hemiodus unimaculatus, species that were captured by the trawl net method, seem to be distributed in a variety of aquatic environments in that area. The gill nets were most productive in the rainy period; by contrast, it obtains richer ichthyofauna in the dry period. It may reflect a higher level of activity in fish populations related to trophy activity that tend to increase at the river margins. Another factor interfering in using gill nets was the covering of dust on the water present in May 2001 , practically simultaneous with the rainy period in that area. This fact, as indicated by Agostinho et al. (1995) may affect the efficiency of this fishery technique.

Furthermore, captures were richer in gill nets with mesh size between 2 and $4 \mathrm{~cm}$. The number of catches decreases in an inverse relation with the increase in mesh size (see Figure 2). The same tendency was verified for the number of captured species of each size by mesh showing the small sized gill nets as more productive. The gill nets with mesh between 5 and $9 \mathrm{~cm}$ had almost null participation in the capture activity of both periods of this study. This fact supports the observations of Santos et al. (2004) and data from Colônia de Pesca Z-35 of Estreito, which revealed a strong decline in the supply of large fishes of business interest in Tocantins River between Estreito and Carolina. As identified above, those verifications are not distant from negative effects caused by the hydroelectric dam of Tucurui that imposed a severe reduction on large fish supply upstream of the dam. On the other hand, frequent species in gill nets with mesh inferior to $5 \mathrm{~cm}$ Hemiodus unimaculatus, represented nearly $40 \%$ of the catch. The gill nets meshed between 2.5 and $3 \mathrm{~cm}$ showed the species Curimata cyprinoides as more representative with about $20 \%$ of the catch. Triportheus albus with $15 \%$ of the catch were the species most frequent in gill nets between 2 and $2.5 \mathrm{~cm}$ and Prochilodus nigricans with about $4 \%$ was predominant in the 3.5 and $4 \mathrm{~cm}$ mesh. It is important to state that juveniles and adults for the species Prochilodus nigricans, Rhaphiodon vulpinus, Plagioscion surinamensis, Steindachnerina amazonica and Boulengerella cuvieri were caught with gill nets of several mesh sizes.The capture with the trawl net revealed

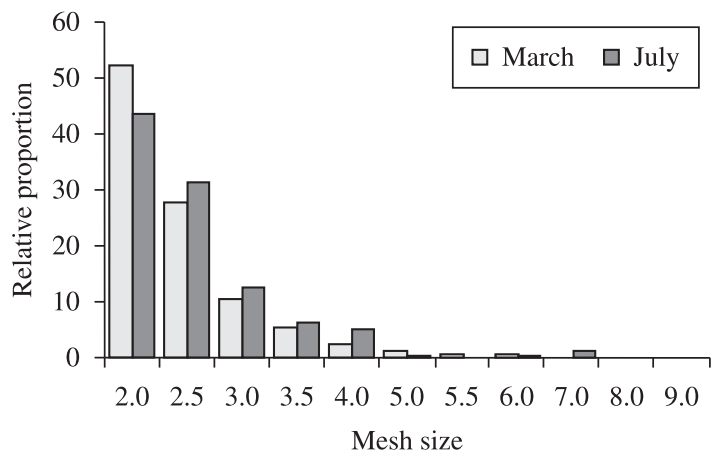

Figure 2. Relative participation of fish capture by mesh size of gill nets in the wet and dry periods. efficiency in the number of species during the dry period, with the species Leptodoras acipenserinus and Hemiodus unimaculatus being the most frequent with this kind of fishing technique. The collection obtained with the help of a trawl net was made only in July, when Tocantins River forms large sanded littorals appropriate for this kind of fishery. The profundity of the river in this period may decrease by almost $4 \mathrm{~m}$ or more in some places, causing shallow waters and resulting in a large concentration of juvenile fish on beaches.

Characterisation of ichthyofauna: According to Merona (1987), 116 species were identified in the confluence of Araguaia and Tocantins drainages before the closure of the Tucurui dam. This system, at that time allowed free communication between the main channel and tributaries favouring the natural spawning of all fish species, but with the construction of the Tucurui dam, the natural flow of Tocantins changed and the migratory fish movements become dependent on the controlled water flow by the hydroelectric power dam. By contrast, this study reveals that only almost 50 simple rustic species, most of them small and medium sized fishes in the Tocantins main channel, were registered. Omnivorous fish like Hemiodus unimaculatus, Steindachnerina amazonica and Curimata species had numerous assemblages and were very common in the captures. The Serrasalmidae Myleus torquatus, Mylossoma duriventre, Myleus sp. are all-herbivorous, or eat fruits, and Serrasalmus rhombeus feeds on fish parts. Mylossoma duriventre that reach $20 \mathrm{~cm} \mathrm{SL}$ or more is nice-looking for fishermen. Other species, Brycon falcatus, species of genus Triportheus, several Tetragonopterinae species and genus Roeboides were also well represented in small mesh. With the exception of Brycon falcatus, which is suitable for fishermen, the remaining species are of little interest for fisheries and are normally included in the category of fish known as "salada" at Estreito's market. Also, the piscivorous species Salminus hilarii and other herbivores of anostomid species such as Leporinus friderici, Leporinus affinis and Schizodon vittatus, reach a medium to large size and are preferred by fishermen of the mid-Tocantins, representing an important item in fisheries but collected in less abundance. In short, from the species formerly recognised as short migratory species, only Brycon falcatus, Salminus hilarii, Prochilodus nigricans, Semaprochilodus brama, Ageneiosus inermis, Pinirampus pirinampu, Pseudoplatystoma fasciatum, Sorubimichthys planiceps and Oxydoras niger were registered in this study.

Large piscivorous fishes of genera Pseudoplatystoma and Brachyplatystoma are species that turn out to be rare in the region of Estreito. Other large siluriform species like Pinirampus pirinampu, Zungaro zungaro and Phractocephalus hemioliopterus are also rare and of them, only P. pirinampu was registered in this study. Other pimelodid fishes, with the exception of genera Pimelodus and Pimelodina have been less encountered despite consisting important items for fisheries in this area. It is important to record that large sized catfishes were perhaps most injured by the advent of 
the Tucurui dam. Barthem and Goulding (1997) identified lower areas in the River Tocantins as places of food supply for these large Amazonian catfishes. With the presence of the Tucurui dam, those species are now unable to migrate upriver of the Tocantins-Araguaia system and this fact may perhaps explain their low occurrence or absence in the study area.

Characteristics of fishery activity in the area: According to Cetra and Petrere (2001), fisheries on the mid-Tocantins have a seasonal pattern. Almost half of the total capture is concentrated between May and August. This fact could be explained by the low level of Tocantins River in this period in parallel with the increase in the density of fish assemblage and presence of large beaches. This situation permits greater efficiency to the fishermen using trawl nets for catching Prochilodus nigricans during their upriver migratory activities. Differently from other Amazonian rivers, where Goulding (1979) recognised fisheries that are regularly possible in natural lakes and in the rainy period, Tocantins fishery produces better yields during the dry period when beaches come up to receive amount of fish populations.

Also the Prochilodus nigricans fisheries on the Tocantins River in this period is favoured by annual recruitment of young fishes at the end of the dry period when juveniles are recruited, leaving flooded areas and migrating upriver to spawn. The obtained data reveals a reduction in capture regarding the number of individuals mainly at the beginning of and during the flood period, contrasting with the species richness which increases. At this time, gill and hand nets become the main fishery gear used by the fishermen. They put in place a large number of gill nets, but capture in terms of individuals is always low. On the other hand, the combination of gill nets in the night period and hand nets during the day period point to a largely diffused strategy employed by fishermen to obtain the best capture during the rainy period in the mid-Tocantins.

Comparing fishery release in 1997 and 1998 at the Imperatriz market studied by Cetra and Petrere (2001) with data obtained from the present study, we may note an increase in species richness in contrast with a reduction in abundance of fish catch. This fact is coincident with the failing of large species of business interest in the mid-Tocantins. Another indication for this reduction in abundance of fish may perhaps be the continuing utilisation by fishermen of gill nets with small size mesh catching a large number of species in detriment of species of commercial interest. When Cetra and Petrere carried out their studies, Hypophthalmus marginatus and Plagioscion squamosissimus were dominant species downriver of Imperatriz. Those authors considered this fact as a prominent result probably derived from the closure of the Tucurui dam. On the other hand, according to Fernando and Holcik (1991), these species may be considered as suitable to survive in the calm environment created by the reservoir of Tucurui hydroelectric power dam.

Furthermore, the study of Cetra and Petrere (2001) showed that species remaining from upper Tucurui dam had to adjust their life cycle to seasonal variations of the
mid-Tocantins. For these authors, at that time Plagioscion squamosissimus was very much overfished in the reservoir, and the pelagic species, Hypophthalmus marginatus, were caught by fishermen on a large scale and this has been the main species entering Imperatriz market. Meanwhile, fishermen assumed new methods for capture appropriate for this aquatic space using large gill nets of low-sized mesh and hand nets, as described by Welcomme (1985) for fisheries in the Amazon as a whole.

Bittencourt and Cox-Fernandes (1990) note that the migratory pattern of Tocantins fish is practically determined by seasonality of capture, maintaining under protection no other migratory species during a good part of the year. This change in utilisation of fishing gear is recognised in this study from the data on fishermen of Colônia Z-35 in Estreito. The fishery data herein studied reveals a considerable reduction in the fish supply brought to Estreito in 1999 and 2000.

Fisheries in the Estreito region are actually centered on the Colônia de Pesca Z-35, assembling fishermen from that city, Carolina and Porto Franco, receiving and distributing fishes from Tocantins in this area. The data collected for this study, plus data obtained near that colony, added to data coming from fisheries in Tocantins River at Imperatriz market published by Cetra and Petrere (2001), report for the region of the mid-Tocantins, 33 species that are economically exploited by fishermen after the Tucurui dam closure.

As can be seen from the data provided by the Colonia de Pesca Z-35 (Figures 3 and 4), the species with major commercial importance during 1999 and 2000 was Colossoma macropomum that reaches almost $40 \mathrm{~cm}$ in length and 6 to $8 \mathrm{~kg}$ in weight. This species is frugivorous and very common in the torrential environments of Tocantins at Estreito. The continuing presence of this species in Tocantins fisheries may be associated with the preference of fishermen to fish in cobblestone habitats in the main channel of the river. They fish in this environment with hand nets and produce a better frequency of fish supply in 1999 and 2000.

On the other hand, studies published ten years before by Eletronorte (1989), indicate Prochilodus nigricans as the most frequent species in the fish supply for Imperatriz market. The data from the colony of Estreito for the present study indicate them as the fifth best represented species in the fisheries of that area. Braga (1990) studied the reproduction and alimentary events from common fishes from the mid-Tocantins and showed the life cycle of Prochilodus nigricans starting in October through to February of the following year when the rain stopped. The other prochilodontid fish current in fisheries at Estreito is Semaprochilodus brama appearing as the second most frequent species in weight at the Colônia de Pesca Z-35 in 1999 and 2000. This species is very much appreciated by the human population of the mid-Tocantins but their assemblages are always reduced in number of individuals, and are more frequent in the reproductive period when migrating through the region of Estreito. 


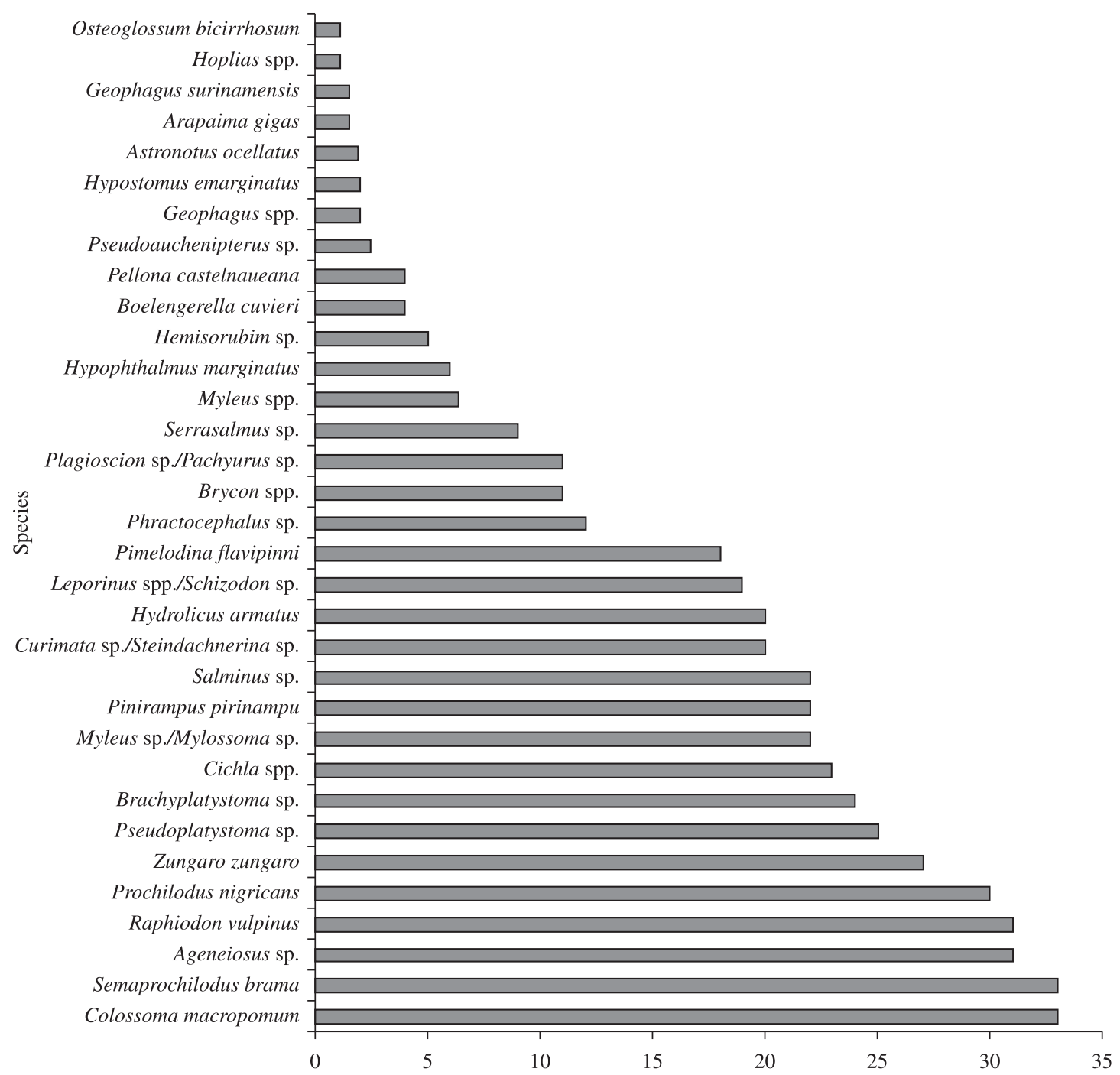

Figure 3. Fish species better represented by weight in Colônia de Pesca at Estreito in 1999.

Other species better represented in terms of fish supply from the colony was Zungaro zungaro that also prefer the cobblestone habitats of the main channel and is fished together with Colossoma macropomum. Other siluriform fish species well represented in fisheries of Estreito was Ageneiosus inermis appearing as the third most frequent species in catches during 1999.

Previous studies on Amazonian fishes (Eletronorte, 1989) revealed the catfish Hypophthalmus marginatus as the dominant planktophagous species, unusual among Siluriformes because it is a species suitable to pelagic zone life. This species had formed numerous assemblages at the mid-Tocantins in the past, mainly at the Tucurui reservoir, being of great importance in fisheries of this region. Nowadays, in light of the data collected for this study, there is strong evidence that this species has become rare at the mid-Tocantins River. Agostinho et al. (1994), reporting on negative impacts on ichthyofauna produced by the Itaipu hydroelectric power dam, detected
Hypophthalmus edentatus accessing the upper Sete Quedas Falls and basically dominating fisheries of that reservoir during the initial years. In the same way, fishermen of Estreito region report Hypophthalmus marginatus as a species that increased in number after the Tucurui reservoir event. In fact, and for an unknown reason, this species has been benefitted with the reservoir formation and this event, observed by Agostinho et al. (1994), would perhaps have occurred in the Tucurui reservoir.

Steindachnerina amazonica and Curimata cyprinoides are very common species at the mid-Tocantins. Those species are detritivorous fishes and after Braga (1990), their first gonadal maturation period occurs early and spawning was registered between November and January. By studying these species, we may infer that they are numerically well represented when in migratory activities, as seen by their actions at the surface in large assemblages at the banks of the Tocantins. 


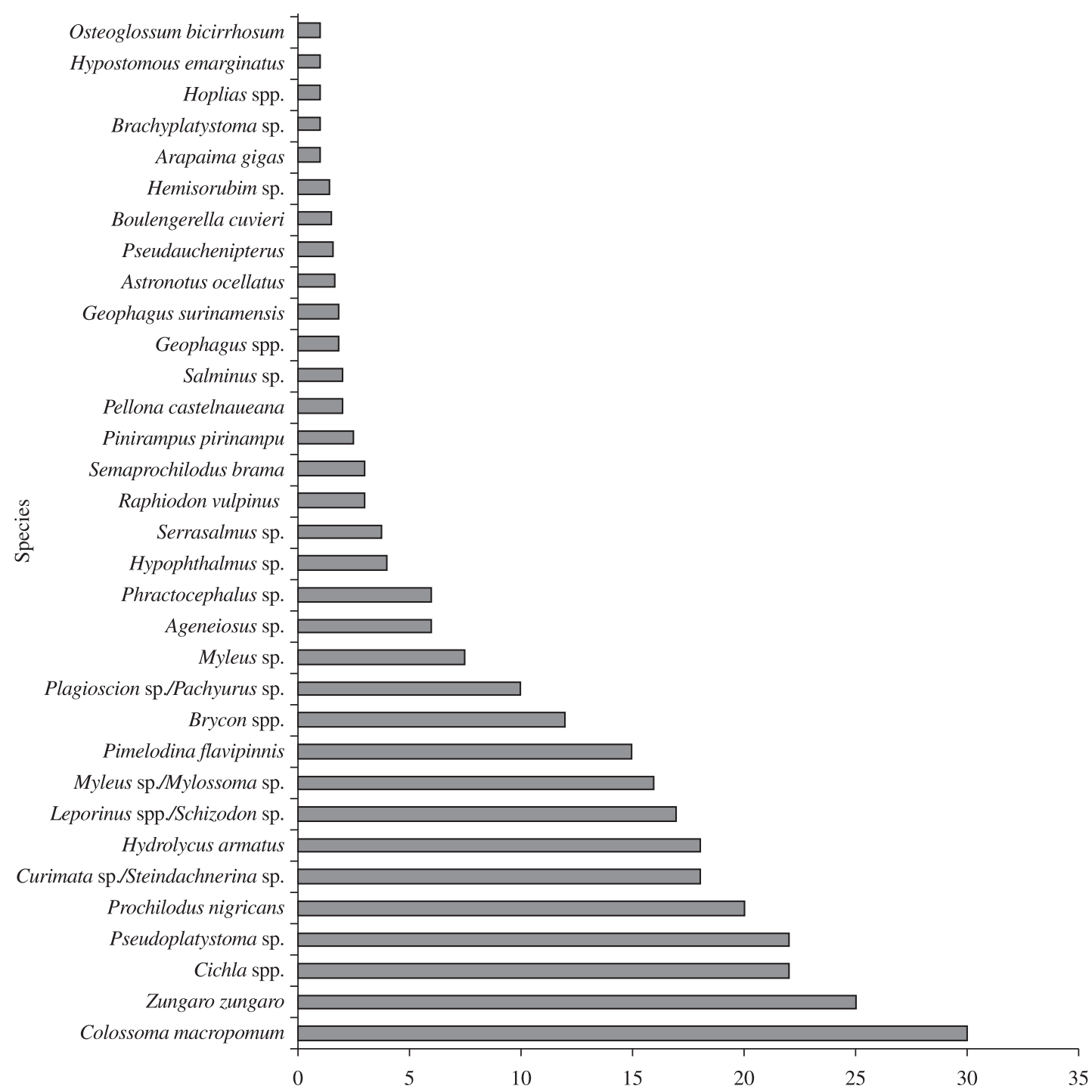

Figure 4. Fish species better represented by weight in Colônia de Pesca at Estreito in 2000.

Furthermore, Hemiodus unimaculatus was the best represented species in the fish captures for this study. With almost $60 \%$ of registers, this almost toothless species feeds on peryphitic algae and plankton. In an optimistic version, this species of low alimentary requirements, well supports hydroelectric reservoirs formed at mid-Tocantins. On the contrary, this species was not well represented in fishermen data obtained from Estreito and perhaps is not a species that is well appreciated by consumers or else local fishermen normally dispense with this species.

The ichthyophagous Cichla temensis and Cichla ocellaris represents a significant part of the fish supply in the Estreito region, the third most important for catches in 2000. Although rare in the main channel of Tocantins, those species originally prefer Amazonian lakes and may have been favoured with the formation of the Tucurui reservoir twenty years ago. Also Plagioscion surinamensis and Pachyurus schomburgkii was very little registered at the Colônia de Pesca Z-35. Those species, very common at mid-Tocantins, such as cichlids, may be well succeeded in the Tucurui reservoir becoming very frequent in the mid-Tocantins. Other predatory species Raphiodon vulpinus and Hydrolycus armatus appear as an important species in fisheries and seem to be other piscivorous species favoured by reservoirs of hydroelectric dams in Tocantins waters.

The fishermen of Estreito recognise reduced migratory fish movements after the construction of Tucurui. The other side of this impoverishment is revealed by this study mainly on migratory species of ichthyofauna, in discovering resident non-migratory species like Geophagus surinamensis, Retroculus lapidifer, Tetragonopterus sp and Plagioscion surinamensis spawning in a different way as showed by Braga (1990) for the large species of ichthyofauna. Furthermore, those species are prone to remain in the new environment imposed by the barrages. 
Fisheries and fishermen at mid-Tocantins River: Adopting the modus operandi of Cetra and Petrere (2001), the following categories of fishermen fish in the Estreito region: a) Subsistent Fishermen: generally living on the banks of the Tocantins banks, having perfect knowledge of the annual cycle of flood and dry seasons, having a subsistence economy. They go fishing alone or in pairs using small boats and simple fishing equipment such as hand nets, gill nets and the "espinhel"; b) Professional Local Fishermen: they live in downtown Carolina, Estreito and Porto Franco and work alone, using powered boats and their fishing equipment consists of trawl nets, gill nets and "caceias" and "anzóis"; c) Professional Barrage Fishermen: they are a nomadic group coming from several regions from the surroundings and use provisional camping houses; they fish mainly at the hydroelectric reservoirs using large gill nets and exploit these places until the decline of fishery productivity; d) Indigenous Fishermen: consisting of Kraô indigenous community housing in the indigenous area located upriver from Estreito, fishing at the tributaries Vermelho and Manuel Alves Pequeno rivers using "arpons", "anzois", "zagaias" and "espinheis", and fishing only for subsistence; e) Sport Fishermen: tourists equipped with large power boats who fish with the help of "molinetes" fishing seasonally. From these categories of fishermen, priority fishery is represented by two of them: that of professional fishermen and subsistence fishery, neither of which execute only one kind of fishery, and both utilising several fishing equipment. On the other hand, migratory fish species are the main object of these fishermen and their fishing is concentrated at the main channel of the Tocantins River.

As indicated by Goulding and Carvalho (1982), some fishery activities are mono or double specific, such as those of Colossoma macropomum in the Amazon basin. This situation of artesanal fisheries was studied by Braga (1990) who listed 57 species captured by the experimental fisheries at mid-Tocantins River. Begossi and Garavello (1990) studied the etnoichthyology in communities and discovered a refined fishery classification enriching the grade of fishery resource. For these authors, the criteria utilised for classifying are morphologic and ecological and the fishermen showed solid knowledge of the environment and its fishes.

In accordance with the available data for the period anterior to the Tucurui hydroelectric power dam, Prochilodus nigricans, Mylossoma duriventre, Colossoma macropomum and the large catfishes Brachyplatystoma filamentosum and Brachyplatystoma sp. were the main species and practically dominated the fisheries at mid-Tocantins. Since the Tucurui closure in 1984, those fisheries were benefitted by an increase in their populations during the first years of the reservoir, but Ribeiro et al. (1995) identify at that time richness of large size fishes produced in the interior of the reservoir. For this author Prochilodus nigricans captures almost doubled and Semaprochilodus brama increased almost fourfold, later decreasing as the reservoir aged. This study revealed that the fish most consumed by the families of fishermen of mid-Tocantins is Prochilodus nigricans and Mylossoma duriventre. In parallel with the data collected by the studies of Leite (1993), this study also revealed a decrease in species richness and fish supply of ichthyofauna over the last ten years. The data provided by colony Z-35 from January to December of 1999 and 2000 agree with this study both registering strong reduction of fisheries in the Estreito region.

The fish discharged at Estreito during these two years and considered as the most important fish by consumers were: Brycon sp, Mylossoma duriventre, Colossoma macropomum, Myloplus schomburgkii, Semaprochilodus brama, Prochilodus nigricans, Osteoglossum bicirrhosum, Plagioscion surinamensis, Cichla temensis, Hydrolycus armatus, Raphiodon vulpinus, Boulengerella cuvieri, Ageneiosus inermis, Hypophthalmus marginatus, Pinirampus pirinampu, Brachyplatystoma vaillantii, Zungaro zungaro, Pimelodina flavipinnis, Pimelodus blochii, Brachyplatystoma filamentosum, Pseudoplatystoma fasciatum, Platystomatichthys sturio and Pimelodella cristata. On the other hand the species classified as less important and secondary fishes were: Schizodon vittatus, Leporinus friderici, Leporinus affinis, Laemolyta fernandezi, Brycon falcatus, Serrasalmus rhombeus, Utiaritichthys sennaebragai, Triportheus angulatus, Triportheus albus, Steindachnerina amazonica, Curimata cyprinoides, Hoplias malabaricus, Hoplerythrinus unitaeniatus, Hemiodus argenteus, Anodus elongatus, Pellona sp, Geophagus surinamensis, Satanoperca jurupari, Heros severus, Parauchenipterus galeatus, Oxydoras niger, Pterygoplichthys sp, Sorubim lima, Phractocephalus hemioliopterus and Sorubimichthys planiceps.

Here we reported an ichthyological situation from the Tocantins River, which has also been observed in other Neotropical basins, e.g. the upper Paraná River basin. As stated by Agostinho et al. (2008), changes and reshaping of fish assemblage structure and function includes the reduction of large migratory fish species populations and the resistance of rustic species of small to medium size which are the majority. We agree with these authors when they state that conservation of the ichthyofauna will be attained only if it includes political, social and scientific effort, and the fishers' knowledge and their activities may be considered relevant by decision makers, when management actions of fish diversity and stocks are put in practice. As the fragmentation of Tocantins basin due to river impoundments for energetic purposes is recent compared to that observed in the Paraná basin, we think that much of the knowledge and experiences obtained in the latter may be applied to fish conservation in the Tocantins River.

Acknowledgements - We are grateful to our colleagues Odney R. Perez-Junior, Vitor O. Lunardi, José L. Birindelli and Fernando Apone when in the Laboratório de Ictiologia Sistemática do Departamento de Ecologia e Biologia Evolutiva da Universidade Federal de São Carlos (LISDEBE) for their help in the field, ichthyological material managements, tabulation and interpretation of taxonomic data. We are also grateful to the 
fishermen Alceno at Estreito and Hélio at Carolina, who greatly helped in the field. We also thank the Direction of Colonia de Pesca Z-35 of Estreito who kindly made the fish data available for comparisons. Juliana P. Garavello and Alexandre K. de Oliveira are grateful to $\mathrm{CNPq}$ for receiving doctoral grants and Julio C. Garavello for the continuation of his CNPq Research grant.

\section{References}

AGOSTINHO, AA., JULIO JÚNIOR, HF. and PETRERE, M., 1994. Itaipu Reservoir (Brasil): impacts of the impoundment on the fish fauna and fisheries. In COWX, IG. (Ed.). Rehabilitation of Freshwater Fisheries. Oxford: Fishing New Books. p. 171-184.

AGOSTINHO, AA., VAZZOLER, AEAM. and THOMAZ, SM., 1995. The High River Paraná Basin: limnological and ichthyological aspects. In TUNDISI, JG., BICUDO, CEM. and MATSUMURATUNDISI, T. (Eds.). Limnology in Brazil. Rio de Janeiro: Brazilian Academy of Science. 376 p.

AGOSTINHO, AA., PELICICE, FM. and GOMES, LC., 2008. Dams and the fish fauna of the Neotropical region: impacts and management related to diversity and fisheries. Brazilian Journal of Biology, vol. 68, no. suppl. 4, p. 1119-1132.

BARTHEM, R. and GOULDING, M., 1997. Os bagres balizadores: ecologia, migração e conservação de peixes amazônicos. Brasília: CNPq. 130 p.

BEGOSSI, A. and GARAVELLO, JC., 1990. Notes on the ethnoicthyology of fishermen from the Tocantins River (Brasil). Acta Amazonica, no. 20, p. 341-351.

BITTENCOURT, MM. and COX-FERNANDES, C., 1990. Peixes migratórios sustentam a pesca comercial. Ciência Hoje, vol. 11 , p. $20-24$.

BRAGA, FMS., 1990. Aspectos da reprodução e alimentação de peixes comuns em um trecho do rio Tocantins entre Imperatriz e Estreito, Estados do Maranhão e Tocantins, Brasil. Revista Brasileira de Biologia = Brazilian Journal of Biology vol. 50, no. 3 , p. 547-558.

CETRA, M. and PETRERE JUNIOR, M., 2001. Small scales fisheries in the medium river Tocantins, Imperatriz (MA), Brazil. Fish Management and Ecology, vol. 8, no. 2, p. 153-162.
ELETRONORTE, 1989. Estudos de viabilidade da UHE Serra Quebrada. Brasília. 161 p. (Relatório Final de Ictiofauna, vol. 1)

FERNANDO, CH. and HOLCIK, J., 1991. Fish in reservoirs. Internationale Revue der Gesamten Hydrobiologie, vol. 76, no. 2, p. 149-167.

GOULDING, M., 1979. Ecologia da pesca do Rio Madeira. Manaus: Instituto Nacional de Pesquisas da Amazônia. 172 p.

GOULDING, M. and CARVALHO, M. L., 1982. Life history and management of the tambaqui (Colossoma macropomum, Characidae): an important Amazonian food fish. Revista Brasileira de Zoologia, vol. 1, no. 2, p. 107-133.

HAHN, NS., AGOSTINHO, AA., GOMES, LC. and BINI, LM., 1998. Estrutura trófica da ictiofauna do reservatório de Itaipu (Paraná, Brasil) nos primeiros anos de sua formação. Interciência, vol. 23 , no. 5 , p. 299-305.

LEITE, RAN., 1993. Efeitos da Usina Hidrelétrica de Tucurui sobre a composição da ictiofauna das pescarias experimentais de malhadeiras realizadas no baixo Tocantins (Pará). Manaus: Instituto Nacional de Pesquisas da Amazônia. 133 p. [Dissertação de Mestrado]

MERONA, B., 1987. Aspectos ecológicos da ictiofauna no baixo Tocantins. Acta Amazonica, vol. 16-17, no. suppl., p. 109-124.

RIBEIRO, MCLB., PETRERE, M. and JURAS, AA., 1995. Ecological integrity and fisheries ecology of the Araguaia-Tocantins River Basin, Brazil. Regulated Rivers: Research \& Management, vol. 2, no. 3-4, p. 325-350.

SANTOS, GM., MERONA, B., JURAS, A. and JÉGU, M., 2004. Peixes do Baixo Rio Tocantins: 20 anos depois da Usina Hidrelétrica Tucuruí. Brasília: Eletronorte. 83 p. (Projeto Tucuruí)

TEJERINA-GARRO, FL., FORTIN, R. and RODRIGUEZ, MA., 1998. Fish community in relation to environmental variation in floodplain lakes in the Araguaia River, Amazon Basin. Environmental Biology of Fishes, vol. 51, no. 4, p. 339-410.

WELCOMME, RL., 1985. River fisheries. London: FAO. 317 p. (Fisheries Technical Paper, no. 262). 
